\title{
Identified FMRFamide-immunoreactive Neuron LPL16 in the Left Pleural Ganglion of Aplysia Produces Presynaptic Inhibition of Siphon Sensory Neurons
}

\author{
S. A. Small, ${ }^{1}$ T. E. Cohen, ${ }^{1,2}$ E. R. Kandel, ${ }^{1,2,3}$ and R. D. Hawkins ${ }^{1,3}$ \\ 'Center for Neurobiology and Behavior, College of Physicians and Surgeons, Columbia University, ${ }^{2}$ Howard Hughes \\ Medical Institute, and ${ }^{3}$ New York State Psychiatric Institute, New York, New York 10032
}

The gill- and siphon-withdrawal reflex of Aplysia undergoes transient inhibition following noxious stimuli such as tail shock. This behavioral inhibition appears to be due in part to transient presynaptic inhibition of the siphon sensory cells, which can be mimicked by application of the peptide FMRFamide. Although FMRFamide is widespread in the Aplysia nervous system, an FMRFamide-containing inhibjtory neuron has not previously been identified. We have searched for such a neuron by combining FMRFamide immunofluorescence with fluorescent dye backfilling from the abdominal ganglion, the location of the siphon sensory cells. These methods localized a neuron in the left pleural ganglion, which we have named LPL16. LPL16 is FMRFamide immunoreactive; it is excited by tail shock; and stimulation of LPL16 produces inhibition of siphon sensory cell-to-motor cell postsynaptic potentials and narrowing of action potentials in the sensory cells in tetraethylammonium solution. These results indicate that LPL16 participates in the inhibitory effects of tail shock, and support the idea that FMRFamide plays a physiological role in the inhibition.

In the higher invertebrates and some vertebrates, it has been possible to identify individual cells in the neural circuit for a behavior and thus to establish a relation between cellular and behavioral events. For example, a number of cells have been identified that participate in mediating the gill- and siphonwithdrawal reflex in Aplysia, and plasticity in those cells has been shown to contribute to plasticity of the reflex (for review, see Hawkins et al., 1987). Several neurons that modulate the reflex have also been identified, including serotonergic facilitator neurons (Hawkins et al., 1981; Mackey et al., 1989). Identification of these modulatory cells has supported the physiological role of 5-HT in presynaptic facilitation contributing to behavioral sensitization of the reflex.

Studies in the last several years have shown that, in addition to sensitization, the gill- and siphon-withdrawal reflex also undergoes transient inhibition following noxious stimuli such as

Received Aug. 29, 1991; revised Nov. 22, 1991; accepted Nov. 25, 1991.

This work was supported by grants from the National Institutes of Health (MH26212) and the Howard Hughes Medical Institute. We thank L. Eliot and J. Koester for their comments, K. Hilten and S. Mack for preparation of the figures, and $H$. Ayers and $A$. Krawetz for typing the manuscript.

Correspondence should be addressed to Dr. Robert D. Hawkins, Center for Neurobiology and Behavior, College of Physicians and Surgeons, Columbia University, 722 West 168 th Street, New York, NY 10032.

Copyright (C) 1992 Society for Neuroscience $0270-6474 / 92 / 121616-12 \$ 05.00 / 0$ tail shock (Krontiris-Litowitz et al., 1987; Mackey et al., 1987; Marcus et al., 1987, 1988). This behavioral inhibition appears to be due in part to transient presynaptic inhibition of the siphon sensory cells by the tail shock (Mackey et al., 1987). This synaptic inhibition can be mimicked by application of the peptide FMRFamide, which acts through the intracellular second messenger arachidonic acid and its lipoxygenase metabolites to open $\mathrm{S}$-type $\mathrm{K}^{+}$channels, narrow action potentials, and decrease transmitter release from the sensory neurons (Abrams et al., 1984; Belardetti et al., 1987; Mackey et al., 1987; Piomelli et al., 1987). Like the facilitation produced by 5-HT, the inhibition produced by FMRFamide undergoes activity-dependent enhancement (Eliot et al., 1989; Small et al., 1989).

Although FMRFamide is widespread in the Aplysia nervous system, there has been no demonstration of an FMRFamidecontaining inhibitory neurnn. Recause other transmitters can also produce presynaptic inhibition of the siphon sensory cells (Abrams et al., 1984; Lukowiak et al., 1986; Goldberg et al., 1987), such a demonstration is necessary to establish a connection between the cellular effects of FMRFamide and behavioral inhibition. We therefore initiated a search for FMRFamidecontaining inhibitory neurons, using techniques similar to those used previously to locate serotonergic facilitator neurons in Aplysia (Hawkins, 1989). In this article we describe identification of a neuron in the left pleural ganglion, which we have named LPL16. We show that LPL16 is FMRFamide immunoreactive, that it is excited by tail shock, and that stimulation of LPL16 produces presynaptic inhibition of the siphon sensory cells.

Preliminary descriptions of some of these results have been presented previously (Mackey et al., 1987; Hawkins and Small, 1988).

\section{Materials and Methods}

Whole-mount immunofluorescence. Juvenile Aplysia californica weighing 1.5-2.0 gm were obtained from the Howard Hughes Mariculture Facility at Miami, FL. Animals were anesthetized by injecting 0.75 $2.00 \mathrm{ml}$ of isotonic $\mathrm{MgCl}_{2}$. The central nervous system (buccal, cerebral, pedal, pleural, and abdominal ganglia) was dissected out and processed for FMRFamide immunofluorescence using a modification of the wholemount technique of Longley and Longley (1986). The nervous system was treated with $0.25 \%$ protease (type XIV, Sigma) in artificial sea water for $20 \mathrm{~min}$ and fixed in $4 \%$ paraformaldehyde in $0.1 \mathrm{~m} \mathrm{Na}$ phosphate (pH 7.4) containing $30 \%$ sucrose at $4^{\circ} \mathrm{C}$ for $24 \mathrm{hr}$. The tissue was rinsed in Triton PBS (0.1 $\mathrm{m}$ Na phosphate, $0.17 \% \mathrm{Na}$ azide, $2 \%$ Triton $\mathrm{X}-100)$, incubated in normal goat serum diluted 1:30 in Triton PBS at room temperature for $3 \mathrm{hr}$, and washed in fresh Triton PBS at $4^{\circ} \mathrm{C}$ for $24 \mathrm{hr}$. The tissue was then incubated for $24 \mathrm{hr}$ in polyclonal rabbit antiFMRFamide antibody (Immuno-Nuclear Corporation, Stillwater, WI) 
diluted 1:500 in Triton PBS. Next, the tissue was washed in Triton PBS for another $24 \mathrm{hr}$ and then incubated for $24 \mathrm{hr}$ in rhodamine-labeled goat anti-rabbit antiserum (Cappel Laboratories, Cochranville, PA) diluted 1:500 or 1:1000 in Triton PBS. After another $24 \mathrm{hr}$ wash in PBS, the tissue was rinsed in $0.03 \mathrm{M}$ Na phosphate buffer solution and mounted on depression slides in glycerol. The slides were viewed with a Leitz epifluorescence microscope using the N2 filter pack (excitation filter, $530-560 \mathrm{~nm}$; mirror, $580 \mathrm{~nm}$; barrier filter, $580 \mathrm{~nm}$ ) and photographed using Kodak 400 ASA film for black-and-white prints. Drawings of the location of immunoreactive neurons in seven nervous systems were used to generate a map of cells that stain reliably. Control nervous systems were treated as above except that the primary antibody was either (1) replaced with whole rabbit serum diluted 1:500 or (2) preabsorbed with FMRFamide (Bachem, Torrance, CA) or FLRFamide (Sig$\mathrm{ma}, \mathrm{St}$. Louis, $\mathrm{MO}$ ) for $24 \mathrm{hr}$ at $4^{\circ} \mathrm{C}$ before application to the tissue. Replacement of the primary antibody or preabsorption with $1 \mathrm{mg} / \mathrm{ml}$ FMRFamide or FLRFamide eliminated staining, and preabsorption with $100 \mu \mathrm{g} / \mathrm{ml}$ FMRFamide or FLRFamide greatly reduced it.

Retrograde fluorescent dye labeling. Nervous systems from juvenile Aplysia were pinned to the Sylgard floor of a Petri dish with the abdominal ganglion placed in a well containing $2 \%$ Lucifer yellow $\mathrm{CH}$ (Sigma, St. Louis, MO) in artificial sea water $(460 \mathrm{~mm} \mathrm{NaCl}, 10 \mathrm{~mm}$ $\mathrm{KCl}, 55 \mathrm{mM} \mathrm{MgCl}_{2}, 11 \mathrm{mM} \mathrm{CaCl}_{2}, 10 \mathrm{~mm}$ HEPES, pH 7.6) supplemented with amino acids, vitamins, sugar, penicillin, and streptomycin (Eisenstadt et al., 1973). The pleural-abdominal connectives were led through a Vaseline seal to a chamber that contained the rest of the nervous system in supplemented artificial sea water without dye. The preparation was incubated at $18^{\circ} \mathrm{C}$ for $5 \mathrm{~d}$, during which time the external solution was changed daily and the Lucifer yellow solution was changed once.

After backfilling, the pleural-abdominal connectives were severed and the ring and buccal ganglia were processed for FMRFamide immunofluorescence as described above. The ganglia were viewed with a Leitz fluorescence microscope using the D filter pack (excitation filter, 355$425 \mathrm{~nm}$; mirror, $455 \mathrm{~nm}$; barricr filter, $460 \mathrm{~nm}$ ) and photographed using Kodak Ektachrome ASA 400 color film. Retrogradely labeled cells exhibit punctate fluorescence in the cytoplasm of the cell body when viewed with the $D$ filter pack. The cell could then be checked for FMRFamide immunofluorescence by switching to the N2 filter pack, with minimal interference between the retrograde and immunofluorescent labeling.

Electrophysiology. To determine the responsiveness of LPL1 6 to cutaneous stimulation a modified split foot preparation (Hening et al., 1979) was employed. Adult Aplysia californica weighing 75-120 gm were obtained from Sea Life Supply (Sand City, CA). Animals were anesthetized by injecting $50 \mathrm{ml}$ of isotonic $\mathrm{MgCl}_{2}$. The animals were dissected in $50 \% \mathrm{MgCl}_{2}, 50 \%$ artificial sea water. The viscera, buccal mass, and opaline gland were excised, and the anterior half of the foot and back were bisected longitudinally, revealing the nervous system and blood vessels. The preparation was then pinned dorsal side up the wax floor of a Lucite recording chamber filled with circulating, aerated artificial sea water. The cut end of the cephalic artery was cannulated and perfused with artificial sea water at room temperature. The left pleural ganglion was pinned on a Sylgard stage and partially desheathed, and the pleural-abdominal connectives were wrapped around stimulation posts to facilitate identification of neurons. Neurons were intpaled with single-barreled glass microelectrodes filled with $2.5 \mathrm{M} \mathrm{KCl}$ for recording and stimulation through a Wheatstone bridge circuit. The skin was stimulated using a glass probe, rat-tooth forceps, or a bipolar capillary electrode administering a $50 \mathrm{~mA} \mathrm{AC}$ shock for $1 \mathrm{sec}$.

To test the effect of intracellular stimulation of LPL16 on siphon sensory-to-motor cell neurotransmission, we used an isolated nervous system preparation. The central nervous system from an adult Aplysia was dissected out, dipped in $0.5 \%$ glutaraldehyde for $45 \mathrm{sec}$, and pinned on a Sylgard stage in a recording chamber where the abdominal and left pleural ganglia were desheathed and perfused with artificial sea water at room temperature. LPL16, an LE siphon sensory neuron, and an LFS siphon motor neuron (identified as described by Byrne et al., 1974; Frost et al., 1988) were impaled with microelectrodes. To measure monosynaptic EPSPs, the motor cell was hyperpolarized $30 \mathrm{mV}$ below resting potential, and single action potentials were evoked in the sensory cell with depolarizing current pulses. EPSPs were considered monosynaptic if their latency was less than $10 \mathrm{msec}$ and constant. To test the effect of LPL16 stimulation on the duration of the action potential in the sensory neurons, LPL16 and a sensory neuron were impaled with microelectrodes and the preparation was perfused with $100 \mathrm{~mm}$ tetraeth- ylammonium chloride (TEA) in artificial sea water. Action potentials were evoked in the sensory cell with $5 \mathrm{msec}$ depolarizing pulses, and the duration of the action potential was measured from the peak to the point on the falling phase that was at $30 \%$ of the peak amplitude, using a laboratory interface to an IBM PC and commercially available software (SPIKE, Hilal Associates, Englewood, NJ).

At the end of all experiments, the candidate L.PI 16 was repenetrated with an electrode filled with $2.5 \%$ Lucifer yellow in deionized water and filled iontophoretically ( $500 \mathrm{msec}, 1-2 \mathrm{nA}$ hyperpolarizing pulses at 1 $\mathrm{Hz}$ for $15-60 \mathrm{~min}$ ). The preparation was then processed for whole-mount immunofluorescence as described above, with both antibodies diluted at 1:50 for use on adult ganglia. Only cells that showed positive FMRFamide immunofluorescence and met the other criteria described below were identified as LPL16.

\section{Results}

Distribution of FMRFamide immunofluorescence in the nervous system of juvenile Aplysia. We observed FMRFamide immunofluorescent neurons in each of the central ganglia (buccal, ccrcbral, lcft and right pedal, left and right pleural, and abdominal) of nervous systems from juvenile Aplysia (Fig. 1). The intensity of the fluorescence varied considerably in the cell bodies of different neurons, suggesting that they may contain different levels of FMRFamide or analogs of FMRFamide recognized to different degrees by the antibody (see Discussion). We also observed FMRFamide immunofluorescent processes surrounding the cell bodies of some neurons (particularly in the cerebral ganglion, not entirely in focus in Fig. 1), in the nerves and connectives, and in the sheath surrounding the ganglia and nerves.

Figure 2 shows a composite drawing of the approximate location, size, and intensity of staining of cells that were FMRFamide immunofluorescent in nervous systems from seven juvenile Aplysia. There are a total of approximately 400 immunofluorescent cells, with about 50 in the buccal ganglion, 100 in the cerebral, 40 in each pleural, 60 in each pedal, and 50 in the abdominal. Abdominal ganglia from several adult animals contained a larger number of FMRFamide-immunoreactive cells, indicating that the number of FMRFamide-immunoreactive cells increases from the juvenile to the adult stages of development.

In agreement with previous studies, we found that the giant cells $\mathrm{R} 2$ (in the abdominal ganglion) and LPL1 (in the left pleural ganglion) are FMRFamide immunoreactive. We have not identified any of the other immunofluorescent cells, but some of them are in the locations of the identified cells L12, L13, LUQ, and R16 in the abdominal ganglion and motor neurons in the buccal ganglion, which previous studies have shown are FMRFamide immunoreactive (Brown et al., 1985; Schaefer et al., 1985; Lloyd et al., 1987).

Localization of potential FMRFamide inhibitory neurons. To localize an FMRFamide-immunoreactive neuron that produces presynaptic inhibition of the siphon sensory cells, we first tested neurons in the abdominal ganglion (the location of the sensory cells), but we have not yet found an FMRFamide inhibitory neuron there. Hawkins et al. (1981) previously identified a neuron in the abdominal ganglion, L16, stimulation of which produces brief hyperpolarization of sensory cells, inhibition of interncurons, and inhibition of complex postsynaptic potentials (PSPs) in motor neurons. However, preliminary results indicate that L16 is not FMRFamide immunoreactive and suggest that it does not produce inhibition of monosynaptic sensory neuronmotor neuron PSPs. Another identified neuron in the abdominal ganglion whose transmitter is unknown, L32, produces a pre- 

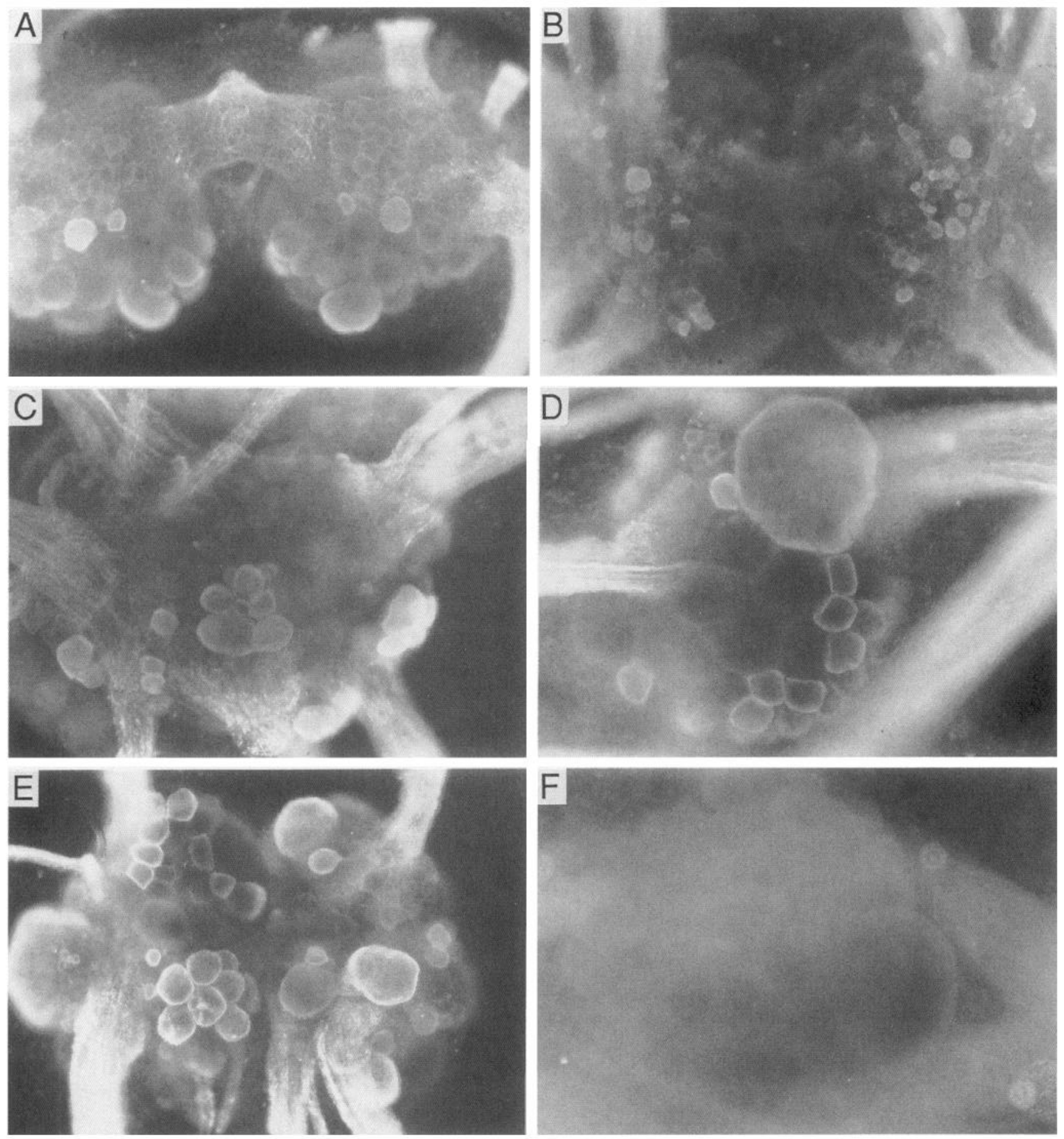

Figure 1. Photographs of FMRFamide immunofluorescence in the nervous system of juvenile Aplysia. A, Ventral buccal ganglion. B, Dorsal cerebral ganglion. $C$, Dorsal right pedal ganglion. $D$, Dorsal left pleural ganglion. $E$, Ventral abdominal ganglion. $F$, Dorsal left pleural ganglion from a control in which whole rabbit serum was substituted for the primary antibody. Scale bar: $400 \mu \mathrm{m}$ for $A-C$ and $E ; 250 \mu \mathrm{m}$ for $D$ and $F$.

synaptic inhibition of L10 (Byrne, 1980; Kretz et al., 1986; Elste et al., 1990), but stimulation of L32 has also not produced inhibition of siphon sensory cells.

We next attempted to localize FMRFamide inhibitory neurons in the other central ganglia by combing two labeling techniques: FMRFamide immunofluorescence and retrograde fluorescent dye labeling from the abdominal ganglion. Together, these techniques label those FMRFamide-immunoreactive neurons in the ring ganglia that send processes to the abdominal ganglion, where the siphon sensory and motor cells are located. Several neurons in the cerebral, pedal, and pleural ganglia exhibited both retrograde labeling from the abdominal ganglion and FMRFamide immunofluorescence and are, therefore, potential FMRFamide inhibitory neurons. We have initially con- 
A

DORSAL

Left
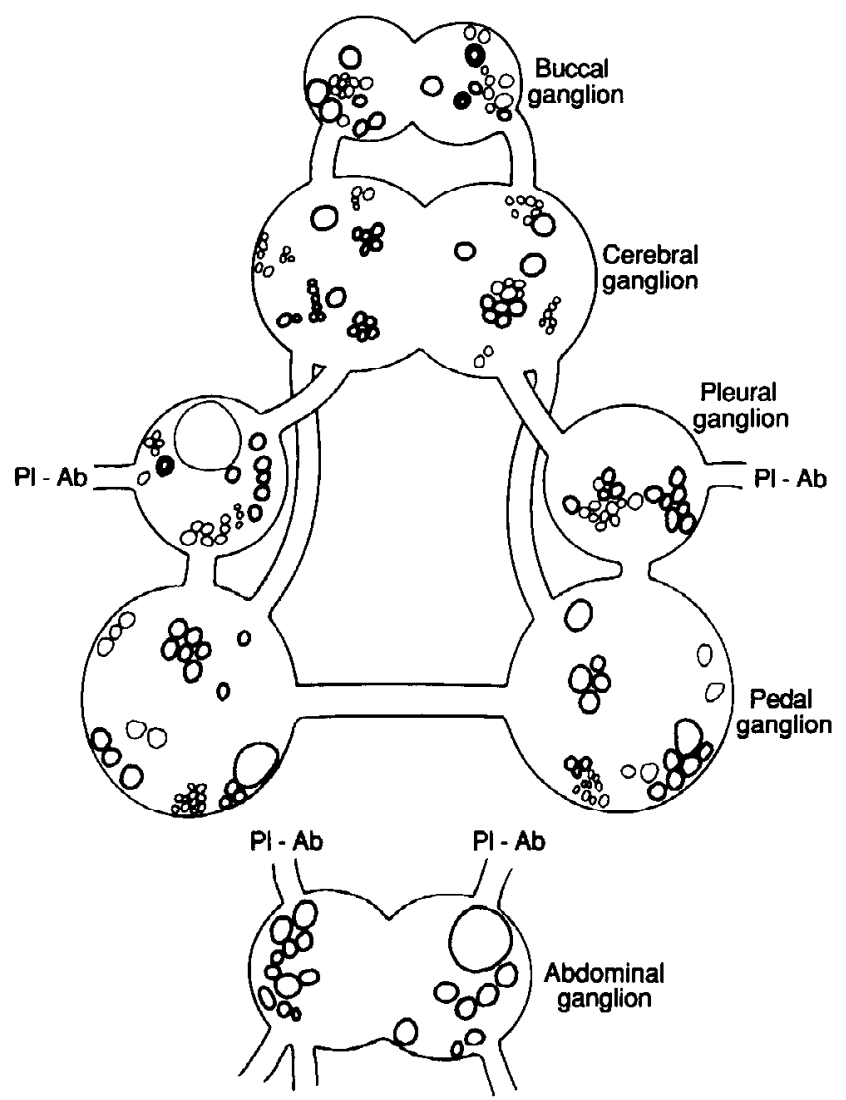

B Right

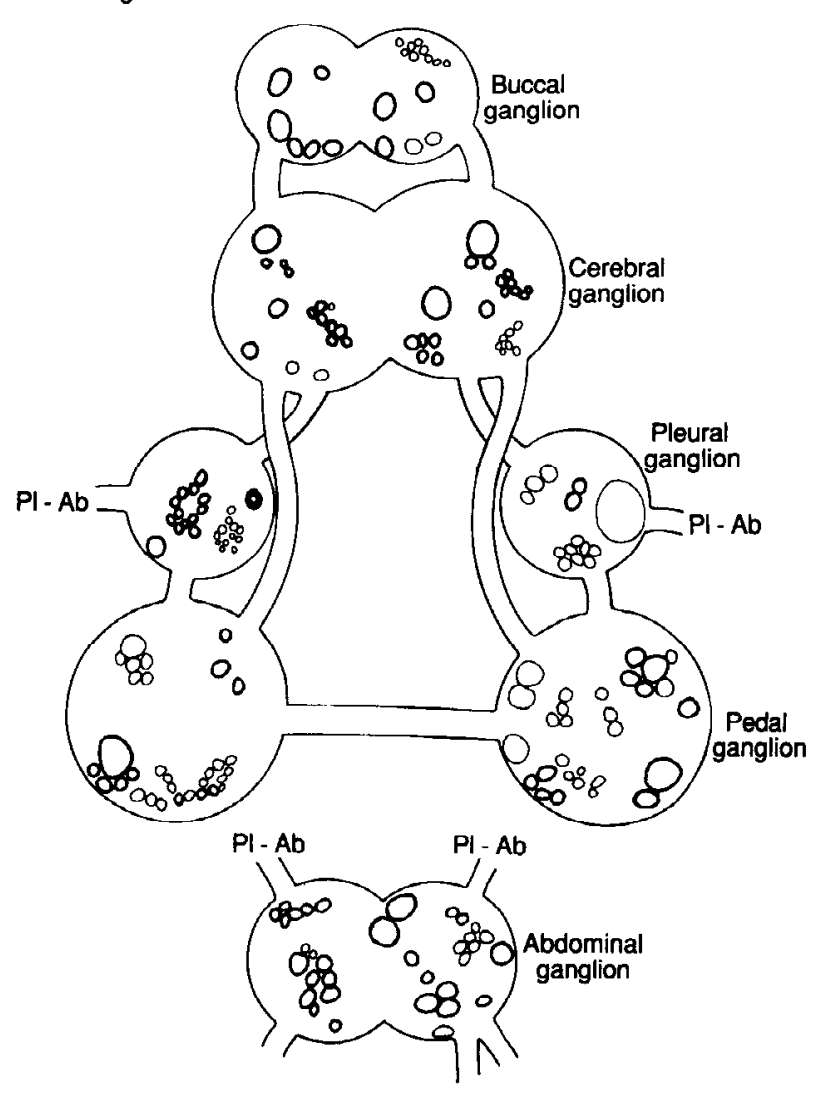

Figure 2. Composite drawing of the approximate location, size, and intensity of staining of cells that are FMRFamide immunoreactive in the nervous system of juvenile Aplysia, based on seven nervous systems mapped in this fashion. $A$, Dorsal view of the dorsal half of the nervous system. $B$, Ventral view of the ventral half of the nervous system. The thickness of the outlines of the cell bodies indicates their relative intensity of staining, $P l-A b$, pleural-abdominal connective.

centrated on one of these, a cell in the left pleural ganglion that reliably double labels. This cell is located on the ventral side of the ganglion in the upper medial quadrant between the giant neuron LPL1 and the pleural-cerebral connective (Fig. 3).

Identification of LPL16. Because the cell shown in Figure 3 backfilled from the abdominal ganglion, it was expected to have an axon in one or both the pleural-abdominal connectives. We therefore searched that region of the left pleural ganglion in vivo for cells that received an antidromic action potential from electrical stimulation of either pleural-abdominal connective, filled them intracellularly with Lucifer yellow, and processed the ganglion for FMRFamide immunofluorescence. As expected from the retrograde labeling experiments, we found a neuron in the left pleural ganglion that received antidromic excitation from the pleural-abdominal connectives and showed positive FMRFamide labeling. Figure 4 shows an example of double labeling of this cell with intracellular Lucifer yellow and FMRFamide immunofluorescence. This figure also illustrates some of the morphological characteristics of this neuron: its cell body is $75-100 \mu_{\mathrm{M}}$ in adult animals, it has fine processes in the pleural ganglion, and its axon bifurcates twice in the ganglion, sending branches out the pleural-abdominal, pleural-pedal, and pleural-cerebral connectives.

After a number of such experiments we were able to determine unique electrophysiological characteristics of this neuron, which are illustrated in Figure 5. The cell has a resting potential of 50$65 \mathrm{mV}$ and is normally silent, with spontaneous EPSPs. Stimulation of the left pleural-abdominal connective produces an action potential that appears to be antidromic (as judged by reliable occurrence and constant latency during high-frequency stimulation, as well as reduction in amplitude when the cell body is hyperpolarized) riding on the rising phase of a slow EPSP. Stimulation of the right pleural-abdominal connective produces an early action potential that appears to be antidromic followed by a flurry of fast EPSPs. Siphon nerve stimulation produces a slow EPSP, which can evoke an action potential. Stimulation of the right P9 pedal nerve produces an action potential that appears to be antidromic followed by a synaptically evoked action potential. This cell can be distinguished from previously identificd cclls of similar size in this region (Shimahara and Tauc, 1976; Fredman and Jahan-Parwar, 1979) because it does not produce an EPSP in the giant cell LPL1. It can also be distinguished from the more recently identified pleural interneuron PLINT (Cleary and Byrne, 1986) because it does not excite the LFS cells, and from InhN (Buonomano et al., 1988 ) because it is FMRFamide immunoreactive. We have therefore given it a new name, LPL16, extending the nomenclature of Fredman and Jahan-Parwar (1979). 


\section{PLEURAL}

Figure 3. Double labeling with fluorescent dye backfilling and FMRFamide immunofluorescence. Cells in the ring ganglia (cerebral, pedal, and pleural) were backfilled from the abdominal ganglion with Lucifer yellow, and the ganglia were processed for FMRFamide immunofluorescence. $A$, The left pleural ganglion viewed with Lucifer yellow filters, showing punctate fluorescent dye backfilling. $B$, The same ganglion viewed with rhodamine filters, showing FMRFamide immunofluorescence. The neuron indicated by the $a r-$ rows reliably labeled with both techniques. $L P L 1$ is identified for orientation.

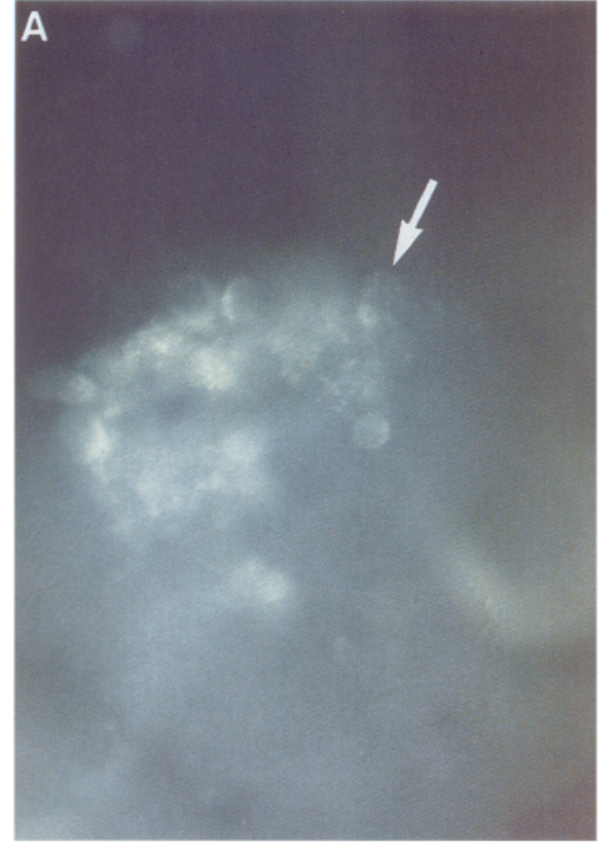

LUCIFER BACKFILL

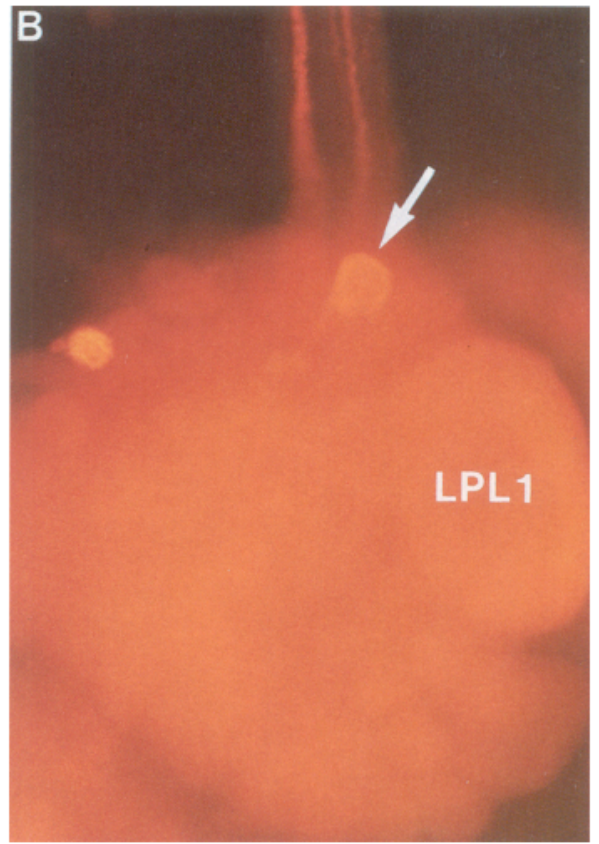

FMRFa

\section{LPL 16}

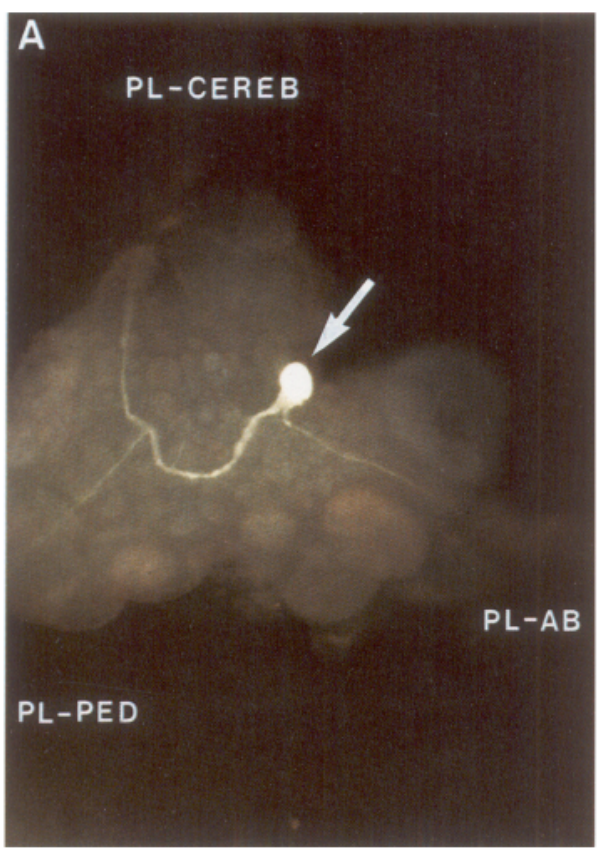

LUCIFER YELLOW

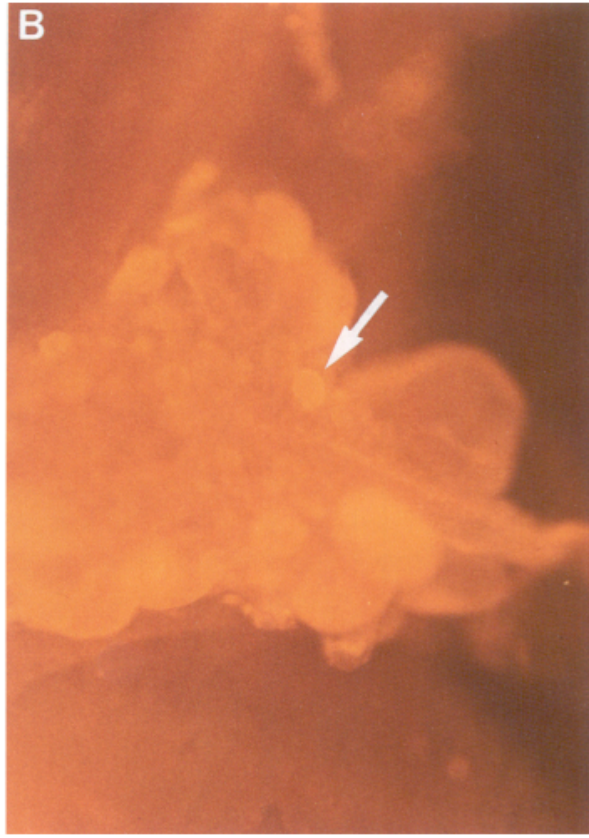

FMRF a showing that the injected cell (arrows) also labels with FMRFamide immualso labels with FMRFamide immunamed LPL16, corresponds to the cell that double-labeled in Figure 3.

Figure 4. Double labeling with intracellular fluorescent dye injection and FMRFamide immunofluorescence. A candidate inhibitor neuron in the left pleural ganglion was injected with Lucifer yellow and the ganglion was processed for FMRFamide immunofluorescence. $A$, The ganglion viewed with injected cell has axons entering the pleural-cerebral ( $P L-C E R E B)$, pleuralpedal $(P L-P E D)$, and pleural-abdominal $(P L-A B)$ connectives. $B$, The same ganglion viewed with rhodamine filters, 


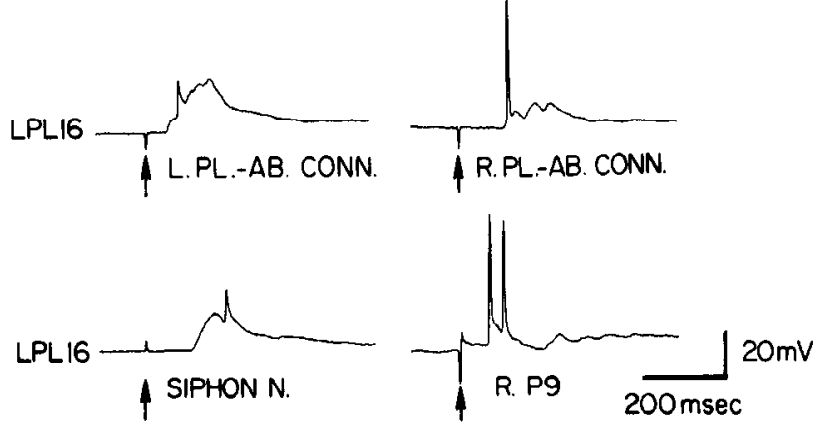

Figure 5. Electrophysiological identification of LPL16. LPL16 receives characteristic antidromic and orthodromic input from stimulation of the left $(L$.$) and right (R$.$) pleural-abdominal connectives (P L$.$A B . C O N N$.), the siphon nerve, and the right $\mathrm{P} 9$ tail nerve. Nerve shock was delivered at the arrows. See the text for details.

In the course of these experiments we encountered another neuron of similar size and electrophysiological properties just anterior to LPL16, which we have named LPL17. LPL17 can be distinguished from LPL16 electrophysiologically in the fol- lowing ways: (1) stimulation of the left pleural-abdominal connective produces an antidromic spike before (rather than after) an EPSP in LPL17, (2) stimulation of the right pleural-abdominal connective produces a spike followed by an afterhyperpolarization (instead of a shower of EPSPs) in LPL17, and (3) stimulation of the right pedal nerve $P 9$ produces more spikes (7-10) in LPL17 than in LPL16. LPL17 is not FMRFamide immunoreactive, and stimulation of it does not produce any change in synaptic transmission from siphon sensory to motor cells, although it does produce a shower of EPSPs in LFS siphon motor neurons.

LPL16 is excited by noxious cutaneous stimulation. To determine whether LPL16 could participate in mediating the inhibitory effects of noxious stimulation, we first recorded the response of LPL16 to cutaneous stimulation in a semi-intact preparation (Fig. $6 A$ ). LPL16 is excited by strong tactile stimulation (pinching) anywhere on the body surface (Fig. $6 B$ ) and fires a burst of about 10 spikes at an average frequency of approximately $40 \mathrm{~Hz}$ in response to tail shock (Fig. $6 \mathrm{C}$ ). These results were seen in several different preparations and could be produced repeatedly in the same preparation.
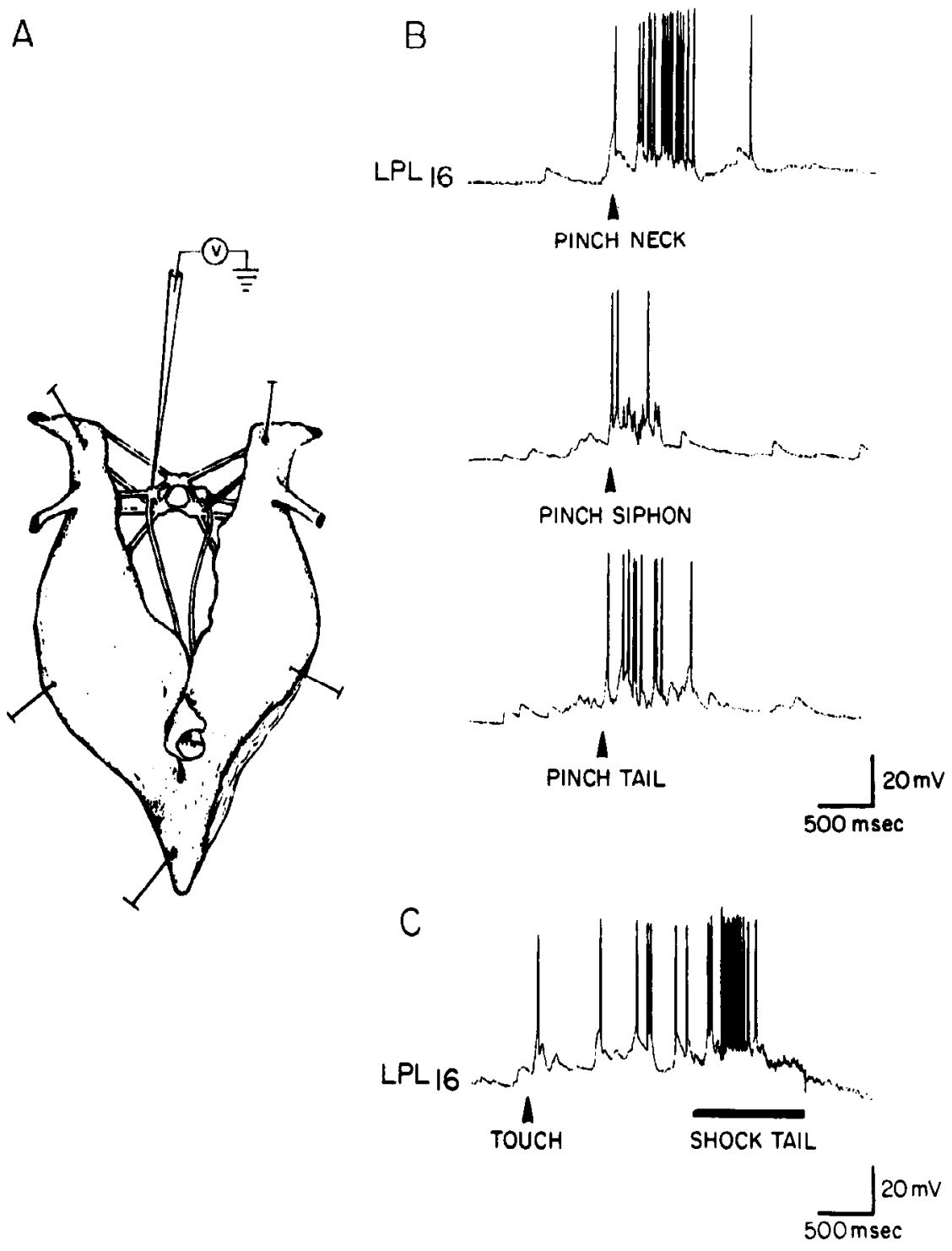

Figure 6. LPL16 is excited by noxious cutaneous stimulation. $A$, Diagram of the semi-intact preparation that we used to record from LPL16 while stimulating the skin. $B$, Responses of LPL16 to strong tactile stimulation (pinching) to the neck, siphon, and tail. $C$, Responses of LPL1 6 to shocking the tail $(50 \mathrm{~mA}$ AC through bipolar capillary electrodes) at the time indicated by the bar. The tail was touched with the electrodes at the arrowhead. 

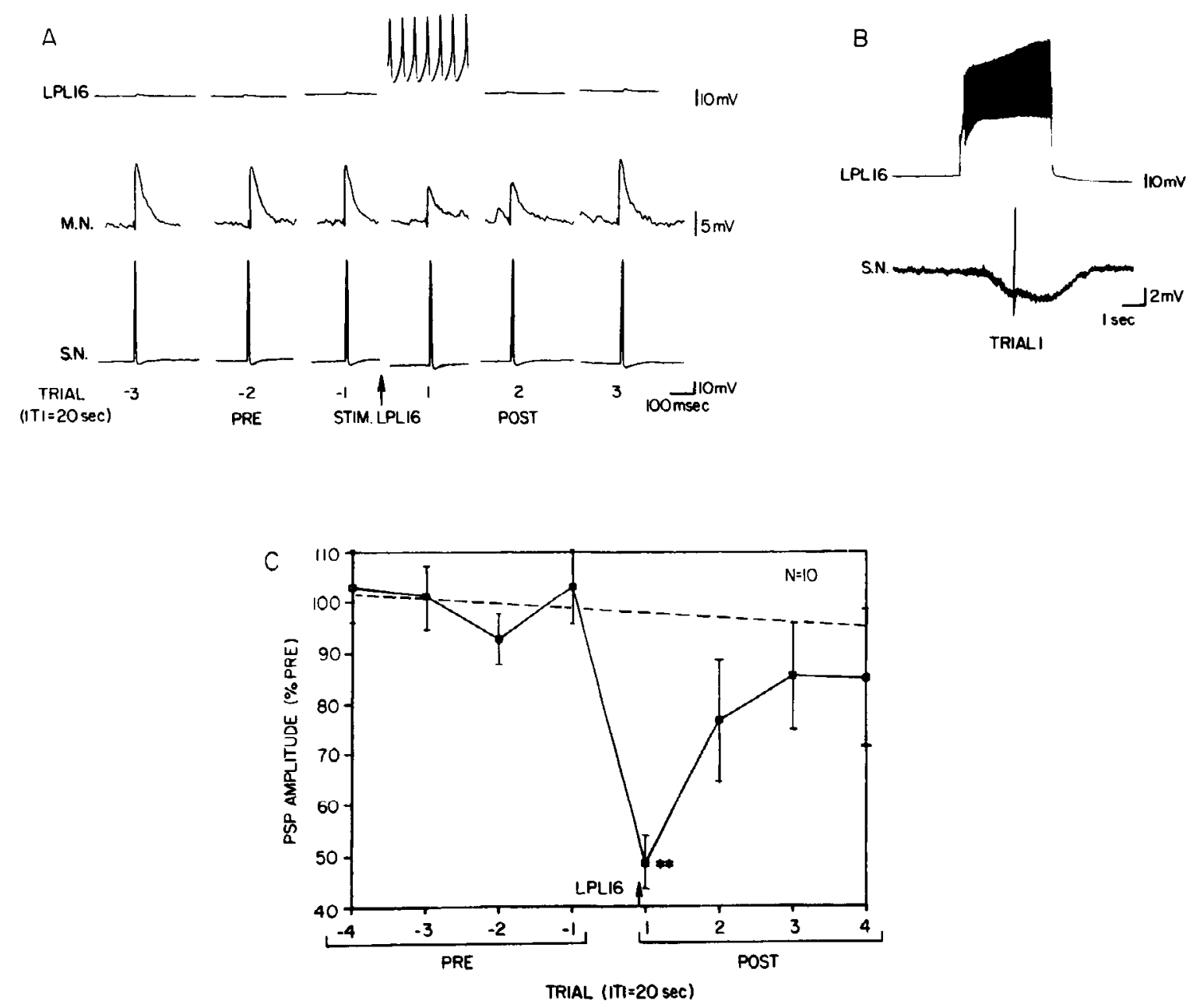

Figure 7. Intracellular stimulation of LPL16 produces inhibition of sensory neuron-motor neuron EPSPs. $A$, Representative experiment. An action potential caused by intracellular current injection in a sensory neuron $(S N$ ) produced an EPSP in a motor neuron (M.N.) with an intertrial interval (ITI) of $20 \mathrm{sec}$ for at least four trials before (Pre) and after (Post) stimulation of LPL16. Brief, high-frequency intracellular stimulation of LPL16 just before and during trial 1 Post produced transient hyperpolarization of the sensory neuron and longer-lasting inhibition of the sensory neuron-motor ncuron EPSP. Only part of the burst of spikes in LPL16 is shown in this record. B. Slower-speed record of the entire burst of spikcs in LPL16 and the hyperpolarization of the sensory neuron in the experiment shown in $A$. $C$, Average results from 10 experiments like the one shown in $A$. The PSP amplitude has been normalized to the average value on the four pretest trials. The broken line has been fitted to those trials by linear regression. LPL16 stimulation occurred at the arrow. The bars indicate SEM, and asterisks indicate a significant difference from the value extrapolated from the pretests (the broken line). On average, LPL16 stimulation produced a decrease in the amplitude of the sensory neuron-motor neuron EPSP, which was maximal immediately after the stimulation and had not fully recovered 1 min later.

Stimulation of LPL16 produces inhibition of EPSPS from siphon sensory cells to motor cells. We next tested whether intracellular stimulation of LPL16, with a pattern roughly similar to its response to tail shock, affects EPSPs from siphon sensory cells to motor cells. We elicited an action potential in an LE sensory cell once every $20 \mathrm{sec}$, and recorded the EPSP it produced in an LFS motor cell. After at least five pretrials, wc stimulated LPL 16 by intracellular current injection, causing it to fire a burst of spikes at an average frequency of approximately $20 \mathrm{~Hz}$ for $3 \mathrm{sec}$, starting about $2 \mathrm{sec}$ before the next trial (Fig. $7 B$ ). Following LPL16 stimulation we recorded the EPSP for at least four more trials.

Figure $7, A$ and $B$, shows the results of a representative experiment. Stimulation of LPL16 produced a decrease in the amplitude of the EPSP measured in the motor cell on the trials during and following LPL1 6 stimulation, as well as a brief (several seconds) hyperpolarization in the sensory neuron. The av- erage results of 10 such experiments are shown in Figure $7 C$. The EPSP amplitude has been normalized to the average value on the four trials before LPL16 stimulation in each experiment [average pretest value (Av. Pre) $=15.2 \mathrm{mV}$ ]. The broken line is a linear regression fit to those four trials, which shows a slight downward trend due to synaptic depression. On average, LPL16 stimulation produced a $52 \%$ decrease in the amplitude of the EPSP on the trial during the stimulation (trial 1 post). The inhibition then declined, but had not completely worn off $1 \mathrm{~min}$ after the stimulation (trial 4 post). The amplitude of the PSP was significantly smaller than the predicted amplitude (the broken line) on the four trials following LPL16 stimulation overall $\left(F_{1,27}=20.57 ; p<0.01\right)$. Planned comparisons at each of the posttests showed that there was a significant effect at the first posttest $\left(F_{1,27}=24.60 ; p<0.01\right)$. These results demonstrate that stimulation of LPL 16 produces inhibition of the EPSP from siphon sensory to motor cells. Moreover, this inhibition is roughly 


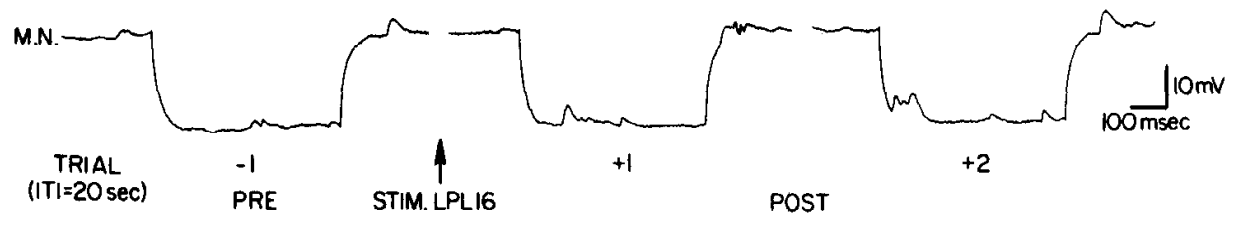

B

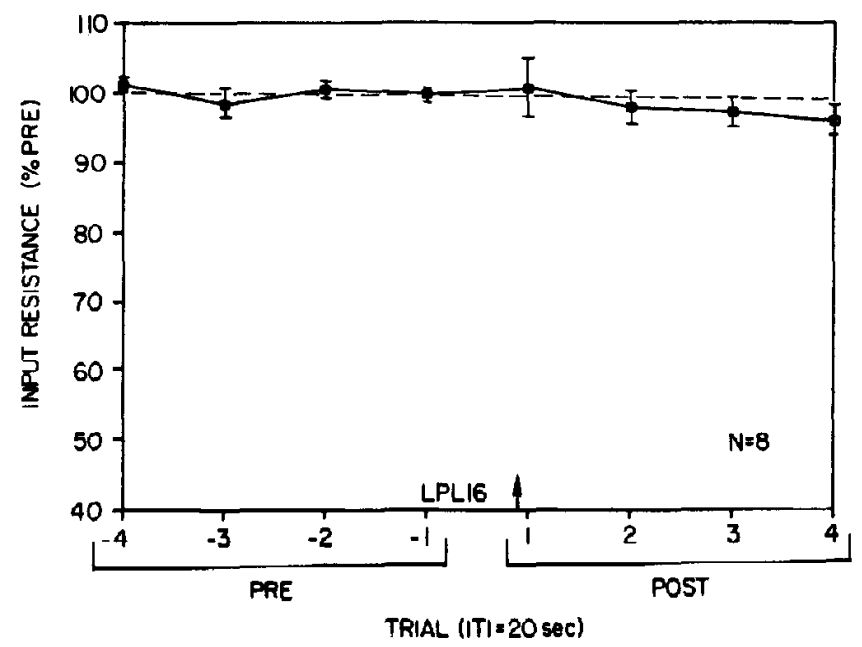

Figure 8. LPL16 stimulation does not alter the input resistance of the motor neuron. $A$, Representative experiment. In 8 of the 10 experiments shown in Figure 7, 2 sec after each evoked EPSP a constant current pulse was injected into the motor neuron, producing a hyperpolarization which is proportional to the input resistance of the motor neuron. Stimulation of LPL 16 did not alter the amplitude of the hyperpolarization. $B$, Average results from the eight experiments. See Figure $7 C$ for explanation. On average, there was no change in the input resistance of the motor neuron following LPL16 stimulation.

$A$

$100 \mathrm{mM}$ TEA

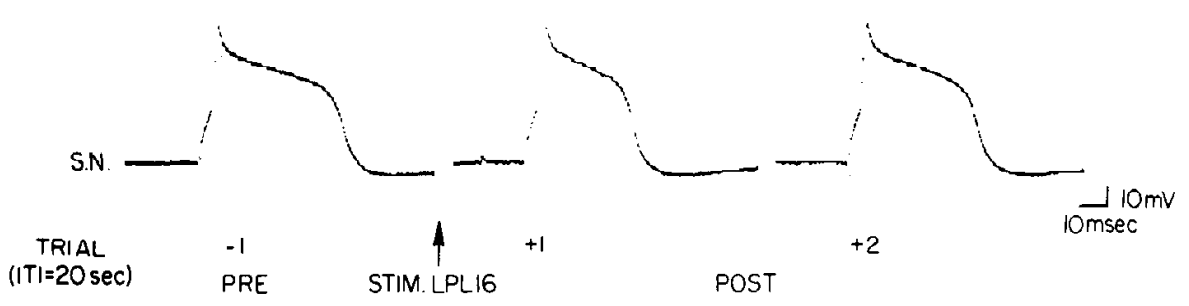

B

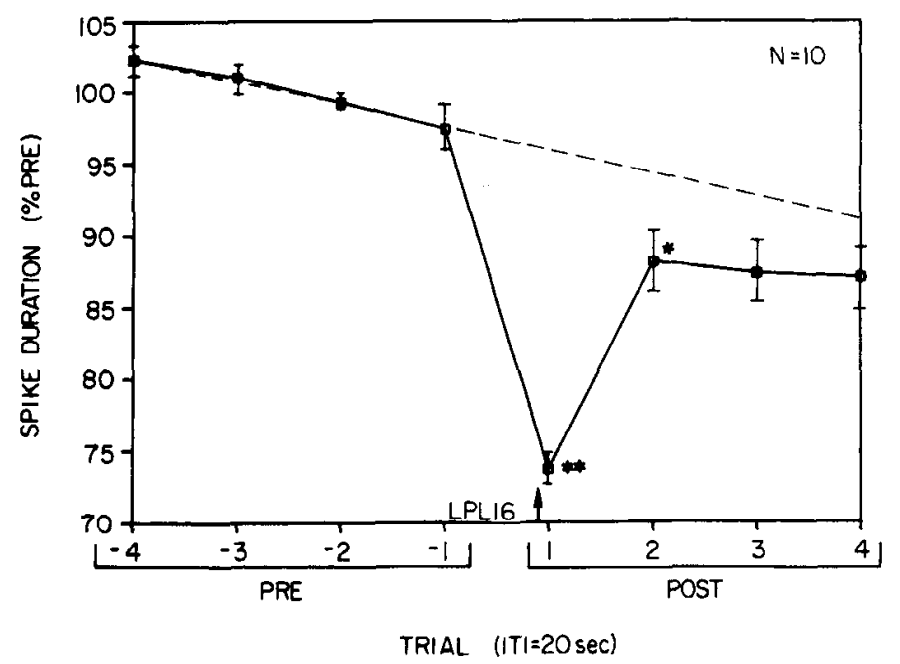

Figure 9. LPL16 produces narrowing of the action potential in the sensory neuron in TEA. $A$, Representative experiment. The design was similar to the experiments shown in Figure 7, except that the nervous system was bathed in artificial sea water containing $100 \mathrm{~mm}$ TEA, and the duration of the action potential in the sensory neuron was measured. Stimulation of LPL16 produced narrowing of the action potential in the sensory neuron. $B$, Average results from 10 experiments like the one shown in $A$. See Figure $7 C$ for explanation. ${ }^{*}, p<.09 ;{ }^{* *}, p<.01$. On average, LPL16 stimulation produced a decrease in spike duration in the sensory neuron, which was maximal immediately after the stimulation and had not fully recovered 1 min later. 
similar in amplitude and duration to the inhibition produced by tail shock (Mackey et al., 1987) or by brief exposure to FMRFamide (Small et al., 1989).

The inhibition produced by LPL16 stimulation has a presynaptic component. The locus of the inhibition produced by LPL16 stimulation might be pre- or postsynaptic. Possible postsynaptic mechanisms include depolarization of the motor cell (decreasing driving force) or a decrease in the input resistance of the motor cell. LPL16 stimulation does not affect the resting potential of the LFS motor neurons, although exogenous FMRFamide has been reported to produce either a depolarization (Small et al., 1989) or hyperpolarization (Belkin and Abrams, 1990) of LFS cells. These different results might be explained by differences in LFS membrane potential or FMRFamide concentration in the different experiments, or by release of a different transmitter or directed transmitter release by LPL16. We tested whether LPL16 affects the input resistance of LFS neurons by measuring the amplitude of the hyperpolarization produced by a constant current pulse in the motor cell $2 \mathrm{sec}$ after each evoked EPSP, in 8 of the 10 experiments described above (Av. Pre $=11.3$ $\mathrm{mV})$. Figure 8 shows the results from a representative experiment and the average results from the eight experiments. There was no significant change in the amplitude of the hyperpolarization $\left(F_{1.27}=1.47\right)$, and thus no change in input resistance of the motor neuron, during and following LPL16 stimulation.

Although this result does not rule out other possible postsynaptic changes, it shifted the focus to presynaptic changes that might occur during the inhibition. Both tail shock and FMRFamide have been shown to act presynaptically, producing narrowing of action potentials in the sensory neurons in the presence of TEA (Abrams et al., 1984; Mackey et al., 1987). FMR Famide causes spikẹ narrowing by both increasing $\mathrm{K}^{+}$current and decreasing $\mathrm{Ca}^{2+}$ current, leading indirectly and directly to a decrease in $\mathrm{Ca}^{2+}$ influx during the action potential and decreased transmitter release from the sensory neuron (Belardetti et al., 1987; Blumenfeld et al., 1990; Edmonds et al., 1990). TEA blocks two components of the $\mathrm{K}^{+}$current, $I_{\mathrm{K}(v)}$ and $I_{\mathrm{K}(\mathrm{C})}$, prolonging the duration of the action potential and making it a more sensitive assay for any changes in the remaining currents. We used this assay to test for possible presynaptic effects of LPL16 stimulation. The protocol was the same as in the previous experiments, except that instead of measuring the amplitude of the PSP in the motor neuron, we measured the duration of the action potential in the sensory neuron in the presence of $100 \mathrm{~mm}$ TEA. Since neurons tend to fire slower in TEA solution, we fired LPL 16 by injecting a train of brief depolarizing pulses at $15 \mathrm{~Hz}$ for $3 \mathrm{sec}$ prior to and during the first posttest in these experiments.

Figure 9 shows the results from a representative experiment and the average results from 10 experiments (Av. Pre $=40.2$ msec). On average, LPL1 6 stimulation produced a $26 \%$ decrease in the duration of the action potential in the sensory neuron on the trial during the stimulation. The spike narrowing then declined, but had not completely worn off 1 min after the stimulation. The duration of the action potential was significantly smaller than the predicted duration (the broken line) on the four trials following LPL16 stimulation overall $\left(F_{1,27}=52.33 ; p<\right.$ 0.01 ). Planned comparisons at each of the posttests showed that this effect was significant at the first $\left(F_{1,27}=75.62 ; p<0.01\right)$ and second $\left(F_{1,27}=5.44 ; p<0.05\right)$ posttests. These results show that stimulation of LPL16 produces narrowing of the action potential in the sensory neurons. This effect is roughly similar in amplitude and duration to the spike narrowing produced by tail shock (Mackey et al., 1987) or brief exposure to FMRFamide (Small et al., 1989). It is also similar in duration to the PSP inhibition produced by LPL16 stimulation (although LPL16 probably released a different amount of transmitter in TEA solution), supporting the idea that the inhibition is at least in part presynaptic. We have not yet analyzed whether the spike narrowing produced by LPL16 is due to an increase in $\mathrm{K}^{+}$current, a decrease in $\mathrm{Ca}^{2+}$ current, or a change in some other current.

\section{Discussion}

FMRFamide immunofluorescence in Aplysia. This is the first systematic mapping of FMRFamide immunoreactive cells in the nervous system of Aplysia. Our results are in general agreement with previous studies. Brown et al. (1985) and Schaefer et al. (1985) reported FMRFamide immunofluorescence in the identitied cells R2, R16, LUQ, L12, and L13 in the abdominal ganglion and LPL1 in the pleural ganglion, as well as a cluster of unidentified cells on the lower right ventral quadrant of the abdominal ganglion and numerous other unidentified cells in the ahdominal, pleural, pedal, and buccal ganglia. Lloyd et al. (1987) also reported FMRFamide immunofluorescence in a few large ventral cells and many small " $\mathrm{S}$ " cells in the buccal ganglion.

We have not identified the immunoreactive neurons in our study other than LPL1 6 and the giant cells R2 and LPL1, but we have seen immunoreactive cells in the same locations as the previous studies. The one exception is the cluster of " $S$ " cells in the buccal ganglion, which were generally only very weakly fluorescent in our experiments (Fig. 1). This may reflect a developmental difference, since we used juvenile Aplysia for our mapping studies. In the few adult ganglia we examined, we saw stronger fluorescence in the " $\mathrm{S}$ " cells. We also saw a larger total number of fluorescent cells in adult ganglia, in agreement with previous reports of an increase in the total number of neurons (Coggeshall, 1967; Cash and Carew, 1989) and the number of monoaminergic neurons (Hawkins, 1989) from the juvenile to the adult stages of development.

FMRFamide immunofluorescence does not necessarily indicate the presence of true FMRFamide. However, previous biochemical studies have demonstrated the existence of true FMRFamide in the nervous system of Aplysia brasiliana (Lehman et al., 1984) and FMRFamide synthesis in the identified cells R2, L12, and L13 in the abdominal ganglion (Schaefer et al., 1985) and B3, 4, 5, 7, and 39 in the buccal ganglion (Church and Lloyd, 1991). Moreover, the Aplysia gene for FMRFamide has been sequenced and shown to contain 28 copies of FMRFamide as well as 1 copy of FLRFamide (Taussig and Scheller, 1986). All of these studies indicate that the FMRFamide antibody probably recognizes true FMRFamide in Aplysia. However, it may also recognize other peptides that include the sequence RFamide, as indicated by biochemical studies showing that the FMRFamide immunoreactive neuron L5 contains a different peptide ending in RFamide (Shyamala et al., 1986), and by our absorption controls, which show that the antibody recognizes FLRFamide as well as FMRFamide.

FMRFamide and inhibition of the gill-and siphon-withdrawal reflex. Previous studies have shown that noxious stimuli such as tail shock produce transient inhibition of the siphon-withdrawal reflex followed by longer-lasting sensitization (KrontirisLitowitz et al., 1987; Mackey et al., 1987; Marcus et al., 1987, 
1988). Tail shock also produces transient presynaptic inhibition of the monosynaptic EPSP from a siphon sensory cell to a motor cell followed by longer-lasting facilitation (Mackey et al., 1987). These synaptic effects are thought to contribute to behavioral inhibition and sensitization of the reflex, respectively. However, although there is good qualitative agreement between the synaptic and behavioral events, the time courses do not match exactly: behavioral inhibition of the siphon component of the reflex lasts 2-3 min, whereas inhibition of the monosynaptic EPSP lasts only about $1 \mathrm{~min}$. More recent studies have shown that behavioral inhibition of the gill and siphon components of the reflex have different time courses, with inhibition of the gill component lasting about $1 \mathrm{~min}$ and matching more closely the time course of inhibition of the monosynaptic EPSP (Hawkins et al., 1990; and R. D. Hawkins, T. E. Cohen, and E. R. Kandel, unpublished observations). These results suggest that behavioral inhibition of the siphon component of the reflex beyond $1 \mathrm{~min}$ may be due to inhibition of siphon-specific interneurons or motor neurons, whereas inhibition of both the gill and siphon components during the first minute after shock is due in part to presynaptic inhibition of the siphon sensory cells.

Application of a humoral factor from shocked animals or the peptide FMRFamide to the abdominal ganglion produces inhibition of the withdrawal reflex (Cooper et al., 1989; KrontirisLitowitz et al., 1989). FMRFamide also mimics the inhibitory effects of tail shock on the sensory neurons, including inhibition of monosynaptic sensory neuron-motor neuron EPSPs, brief hyperpolarization of the sensory cells, and narrowing of action potentials in the sensory neurons in TEA (Abrams et al., 1984; Mackey et al., 1987; Piomelli et al., 1987). These inhibitory effects of FMRFamide on the sensory neurons are mediated through the second messenger arachidonic acid and its lipoxygenase metabolites, which act in part by opening $\mathrm{S}-\mathrm{K}^{+}$channels (Belardetti et al., 1987; Piomelli et al., 1987). FMRFamide also decreases $\mathrm{Ca}^{2+}$ current, $\mathrm{Ca}^{2+}$ influx, and spontaneous transmitter release from sensory neurons, and dephosphorylates specific proteins in those neurons (Sweatt et al., 1989; Blumenfeld et al., 1990; Dale and Kandel, 1990; Edmonds et al., 1990)-it is not yet known whether these effects are also mediated through arachidonic acid. An inhibitor of arachidonic acid metabolism blocks inhibition of the sensory neurons by tail shock, consistent with the idea that the inhibitory effects of shock are mediated through FMRFamide stimulation of arachidonic acid (Mackey et al., 1988).

An identified FMRFamide-immunoreactive inhibitory neuron. Immunocytochemical and biochemical studies have shown that FMRFamide is present and synthesized in the abdominal ganglion, the location of the siphon sensory cells (Brown et al., 1985; Schaefer et al., 1985). However, other transmitters, including dopamine, arginine vasotocin, and enkephalin, can also produce inhibition of the sensory cells (Tomosky-Sykes, 1978; Abrams et al., 1984; Lukowiak et al., 1986; Goldberg et al., 1987) and inhibit the reflex (Cooper et al., 1989), raising questions about the physiological role of FMRFamide. We therefore initiated a search for FMRFamide-containing neurons that might mediate the inhibitory effects of tail shock on the sensory cells. We first tested neurons in the abdominal ganglion but have not yet found an FMRFamide inhibitory neurons there. We next searched for potential FMRFamide-containing inhibitory neurons in the other central ganglia, using methods similar to those used previously to locate serotonergic facilitator neurons (Hawkins, 1989). That is, we combined FMRFamide immunofluo- rescence with fluorescent dye (Lucifer yellow) backfilling from the abdominal ganglion. This method locates FMRFamide-immunoreactive neurons in the other ganglia that send an axon to the abdominal ganglion and are therefore potential inhibitors of the siphon sensory cells. We located several double-labeled neurons and have initially concentrated on one of these, a cell in the left pleural ganglion. Since we believe this cell has not previously been identified, we have given it a new name, LPL16, following the nomenclature of Fredman and Jahan-Parwar (1979). LPL16 is excited by noxious stimuli such as tail shock, and intracellular stimulation of LPL16 produces inhibition of monosynaptic sensory neuron-motor neuron EPSPS. LPL16 stimulation also produces brief hyperpolarization of the sensory cells and narrowing of action potentials in the sensory neurons in TEA, suggesting that the inhibition is at least in part presynaptic. These findings indicate that LPL16 participates in the inhibitory effects of tail shock. Since LPL16 is FMRFamide immunoreactive, these findings also support the idea that FMRFamide plays a physiological role in the inhibition.

Several questions about LPL16 need further investigation. First is its transmitter identity. Two lines of evidence indicate that LPL16 contains and releases FMRFamide: immunofluorescent labeling and similarity of physiological effects on the sensory cells. That is, both LPL16 and FMRFamide produce inhibition of sensory neuron-motor neuron EPSPs, brief hyperpolarization of sensory cells, and narrowing of action potentials in the sensory cells in TEA (Abrams et al., 1984; Mackey et al., 1987; Piomelli et al., 1987). Moreover, the time courses of the inhibition and spike narrowing are roughly similar with I.PI.16 stimulation and brief application of FMRFamide (Small et al., 1989). However, neither type of evidence is completely specific, and LPL16 might contain more than one transmitter (e.g., Lloyd et al., 1987; Church and Lloyd, 1991). Additional biochemical or histochemical evidence will therefore be required to establish firmly whether LPL16 utilizes FMRFamide as a transmitter.

Second, we know that LPL16 sends an axon to the left abdominal ganglion (the location of the siphon sensory cells), but we do not know whether its effects on the sensory cells are direct or whether they are produced indirectly by exciting some other neuron. We have found no connection between LPL16 and the abdominal inhibitory neuron L16, but other neurons might be involved. The directness of modulatory effects is difficult to test definitively in the ganglion, but such a test may be possible in isolated cell culture (see Hawkins and Schacher, 1989).

Third, we do not know how much LPL16 contributes to the inhibitory effects of tail shock on the sensory neurons. The inhibition of the PSP and narrowing of the action potential produced by intracellular stimulation of LPL16 are comparable in both magnitude and duration to the effects produced by tail shock (Mackey et al., 1987). However, in these experiments we fired more spikes in LPL1 6 with intracellular stimulation (approximately 60 spikes at $20 \mathrm{~Hz}$ ) than it usually fires in response to tail shock (approximately 10 spikes at $40 \mathrm{~Hz}$ ), suggesting that LPL16 may not account for all of the effects of tail shock, although the higher frequency of firing produced by the tail shock may be more effective. Two additional arguments make it seem likely that other neurons are involved. First, tail shock also excites facilitator neurons that counteract the inhibition, so the net inhibition observed probably underestimates the total inhibition produced by tail shock (Hawkins et al., 1981; Mackey et al., 1989). Second, we observed several other FMRFamide- 
immunoreactive neurons that backfilled from the abdominal ganglion and that are therefore potential inhibitors of the sensory cells. Moreover, other transmitters besides FMRFamide can produce inhibition of the sensory cells (Abrams et al., 1984; Lukowiak et al., 1986; Goldberg et al., 1987). It is not yet known, however, whether these other neurons and transmitters play a physiological role in the effects of tail shock. It will be necessary to hyperpolarize LPL16 during tail shock to determine its quantitative contribution. The present data indicate that LPL16 does, however, make some contribution to the inhibitory effects of shock.

Modulatory systems in Aplysia. These and previous studies show that tail shock excites two different populations of neurons that modulate the gill- and siphon-withdrawal reflex, including FMRFamide-immunoreactive inhibitory neurons (LPL16) and serotonergic facilitatory neurons (CB1; Mackey et al., 1989). Further characterization of these neurons should make it possible to address several additional issues concerning the organization of neuromodulatory systems in Aplysia. (1) Is LPL16 excited by appetitive stimuli that produce inhibition of the withdrawal reflex, such as feeding and copulation (Advokat, 1980; Lukowiak, 1980; Lukowiak and Fredman, 1983), or is it only excited by aversive stimuli? (2) Does LPL16 affect other cells besides the siphon sensory cells? In particular, does it produce inhibition at other sites in the gill- and siphon-withdrawal circuit such as interneurons or motor neurons? Also, does it produce inhibition of cells involved in other reflexes, such as the pleural or cerebral mechanosensory neurons? FMRFamide produces narrowing of action potentials in the former ( $R$. D. Ilawkins, unpublished observations) and either narrowing or broadening of action potentials in the latter (Rosen et al., 1989); it will be interesting to see if stimulation of LPL16 mimics these effects. (3) Does LPL16 have synaptic connections (either excitatory or inhibitory) with other known modulatory neurons in Aplysia such as L29 and CB1 (modulators of gill and siphon withdrawal, Hawkins et al., 1981; Mackey et al., 1989), PLINT and InhN (modulators of tail withdrawal; Cleary and Byrne, 1986; Buonomano et al., 1988), and MCC and CPR (modulators of food arousal; Weiss et al., 1982; Teyke et al., 1990)? Information about the connections of these neurons should make it possible to begin to analyze the hierarchical structure of modulatory systems in Aplysia and to determine the functional consequences of that structure. (4) The method we used to locate LPL16 (combining histofluorescence with retrograde fluorescent labeling) was previously used to locate serotonergic facilitator neurons in Aplysia (Hawkins, 1989), and should be useful in locating yet additional modulatory neurons of other transmitter types (such as the small cardioactive peptide SCP or dopamine) to add to this body of knowledge about Aplysia modulatory systems.

\section{References}

Abrams TW, Castellucci VF, Camardo JS, Kandel ER, Lloyd PE (1984) Two endogenous neuropeptides modulate the gill and siphon withdrawal reflex in Aplysia by means of presynaptic facilitation involving cyclic AMP-dependent closure of a serotonin-sensitive potassium channel. Proc Natl Acad Sci USA 81:7956-7960.

Advokat C (1980) Modulation of defensive reflexes in Aplysia californica by appetitive stimulation. Behav Neurol Biol 28:253-265.

Belardetti F, Kandel ER, Siegelbaum SA (1987) Neuronal inhibition by the peptide FMR Famide involves opening of $\mathrm{S} \mathrm{K}^{+}$channels. Nature 325:153-156.

Belkin KJ, Abrams TW (1990) FMRFamide acts in parallel pre- and postsynaptically, via arachidonic acid, to inhibit the neural circuit of the siphon withdrawal reflex of Aplysia. Soc Neurosci Abstr 16:627.

Blumenfeld H, Spira ME, Kandel ER, Siegelbaum SA (1990) Facilitatory and inhibitory transmitters modulate calcium influx during action potentials in Aplysia sensory neurons. Neuron 5:487-499.

Brown RO, Gusman D, Basbaum AI, Mayeri E (1985) Identification of Aplysia neurons containing immunoreactive FMRFamide. Neuropeptides $6: 517-526$.

Buonomano D, Cleary LJ, Byrne JH (1988) Inhibitory interneuron produces heterosynaptic inhibition of the sensory-motor connection mediating the tail withdrawal reflex of Aplysia. Soc Neurosci Abstr 14:841.

Byme J, Castellucci V, Kandel ER (1974) Receptive fields and response properties of neurons innervating siphon skin and mantle shelf in Aplysia. J Neurophysiol 37:1041-1064.

Byrne JH (1980) Identification of neurons contributing to presynaptic inhibition in Aplysia californica. Brain Res 199:235-239.

Cash D, Carew TJ (1989) A quantitative analysis of the development of the central nervous system in juvenile Aplysia californica. J Neurobiol 20:25-47.

Church P.I, Lloyd PE (1991) Expression of diverse neuropeptide cotransmitters by identified motor neurons in Aplysia. J Neurosci 11 : $618-625$.

Cleary LJ \& Byrne JH (1986) Associative learning of the gill and siphon withdrawal reflex in Aplysia: interneurons mediating the unconditioned response. Soc Neurosci Abstr 12:397.

Coggeshall RE (1967) A light- and electron-microscopic study of the abdominal ganglion of Aplysia californica. J Neurophysiol 30:12631287.

Cooper BF, Krontiris-Litowitz JK, Walters ET (1989) Humoral factors released during trauma of Aplysia body wall. II. Effects of possible mediators. J Comp Physiol [B] 159:225-235.

Dale N, Kandel ER (1990) Facilitatory and inhibitory transmitters modulate spontaneous transmitter release at cultured Aplysia sensorimotor synapses. J Physiol (I ond) 421:203-222.

Edmonds B, Klein M, Dale N, Kandel ER (1990) Contributions of two types of calcium channels to synaptic transmission and plasticity. Science 250: 1142-1147.

Eisenstadt M, Goldman JE, Kandel ER, Koike H, Koester J, Schwartz $\mathrm{JH}$ (1973) Intrasomatic injection of radioactive precursors for studying transmitter synthesis in identifed neurons of Aplysia californica. Proc Natl Acad Sci USA 70:3371-3375.

Eliot LS, Schacher S, Kandel ER, Hawkins RD (1989) Pairing-specific activity-dependent facilitation of Aplysia sensory-motor neuron synapses in isolated culture. Soc Neurosci Abstr 15:483.

Elste A, Koester J, Shapiro E, Panula P, Schwartz JH (1990) Identification of histaminergic neurons in Aplysia. J Neurophysiol 64:736744.

Fredman SM, Jahan-Parwar B (1979) Intra- and interganglionic synaptic connections in the CNS of Aplysia. Brain Res Bull 4:393-406.

Frost WN, Clark GA, Kandel ER (1988) Parallel processing of shortterm memory for sensitization in Aplysia. J Neurobiol 19:297-334.

Goldberg J, Colmers W, Edstrom J, Lukowiak K (1987) Suppression of sensory to motor synaptic transmission and narrowing of the sensory neurone action potential by arginine vasotocin in Aplysia californica. J Exp Biol 128:47-62.

Hawkins RD (1989) Localization of potential serotonergic facilitator neurons in Aplysia by glyoxylic acid histofluorescence combined with retrograde fluorescent labeling. J Neurosci 9:4214-4226.

Hawkins RD, Schacher S (1989) Identified facilitator neurons L29 and L28 are excited by cutaneous stimuli used in dishabituation, sensitization, and classical conditioning of Aplysia. J Neurosci 9:42364245.

Hawkins RD, Small SA (1988) An identified FMRFamide-immunoreactive neuron produces presynaptic inhibition of the siphon sensory neurons in Aplysia. Soc Neurosci Abstr 14:842.

Hawkins RD, Castellucci VF, Kandel ER (1981) Interneurons involved in mediation and modulation of gill-withdrawal reflex in $A p l y$ sia. II. Identified neurons produce heterosynaptic facilitation contributing to behavioral sensitization. J Neurophysiol 45:315-326.

Hawkins RD, Clark GA, Kandel ER (1987) Cell biological studies of learning in simple vertebrate and invertebrate systems. In: Handbook of physiology, Sec 1, The nervous system, Vol V, Higher functions of the nervous system, Pt 1 (Mountcastle VB, Plum F, Geiger SR, eds), pp 25-38. Bethesda, MD: American Physiological Society. 
Hawkins RD, Cohen TE, Henzi VA, Kandel ER (1990) Parallel dishabituation and sensitization with no inhibition of gill-withdrawal reflex in Aplysia. Soc Neurosci Abstr 16:19.

Hening WA, Walters ET, Carew TJ, Kandel ER (1979) Motorneuronal control of locomotion in Aplysia. Brain Res 179:231-253.

Kretz R, Shapiro E, Kandel ER (1986) Presynaptic inhibition produced by an identified presynaptic inhibitory neuron. I. Physiological mechanisms. J Neurophysiol 55:113-130.

Krontiris-Litowitz J, Coooper BF, Walters ET (1989) Humoral factors released during trauma of Aplysia body wall. I. Body wall contraction, cardiac modulation, and central reflex suppression. J Comp Physiol [B] 159:211-223.

Krontiris-Litowitz JK, Erickson MT, Walters ET (1987) Central suppression of defensive reflexes in Aplysia by noxious stimulation and by factors released from body wall. Soc Neurosci Abstr 13:815.

Lchman HK, Price DA, Grecnberg MJ (1984) The FMRFamidc-like neuropeptide of Aplysia is FMRFamide. Biol Bull 167:460-466.

Lloyd PE, Frankfurt M, Stevens P, Kupfermann I, Weiss KR (1987) Biochemical and immunocytological localization of the neuropeptides FMRFamide, $\mathrm{SCP}_{\mathrm{A}}, \mathrm{SCP}_{\mathrm{B}}$ to neurons involved in the regulation of feeding in Aplysia. J Neurosci 7:1123-1132.

Longley RD, Longley AJ (1986) Serotonin immunoreactivity of neurons in the gastropod Aplysia californica. J Neurobiol 17:339-358.

Lukowiak K (1980) CNS control over gill reflex behaviors in Aplysia: satiation causes an increase in the suppressive control in older but not younger animals. J Neurobiol 1 1:591-611.

Lukowiak K, Fredman L (1983) The gill withdrawal reflex in sexually active Aplysia is suppressed. Can J Physiol Pharmacol 61:743-748.

Lukowiak K, Goldberg JI, Colmers WF, Edstrom JP (1986) Peptide modulation of neuronal activity and behavior in Aplysia. In: Comparative aspects of opioid and related neuropeptide mechanisms (Stefano G, Leung M, eds), pp 129-144. Boca Raton, FL: CRC.

Mackey SL, Glanzman DL, Small SA, Dyke AM, Kandel ER, Hawkins RD (1987) Tail shock produces inhibition as well as sensitization of the siphon-withdrawal reflex of Aplysia: possible behavioral role for presynaptic inhibition mediated by the peptide Phe-Met-Arg-Phe$\mathrm{NH}_{2}$. Proc Natl Acad Sci USA 84:8730-8734.

Mackey SL, Lalevic N, Hawkins RD, Kandel ER (1988) Comparison of dishabituation and sensitization of the gill-withdrawal reflex in Aplysia. Soc Neurosci Abstr 14:842.

Mackey SL, Kandel ER, Hawkins RD (1989) Identified serotonergic neurons LCB1 and RCB1 in the cerebral ganglia of Aplysia produce presynaptic facilitation of siphon sensory neurons. J Neurosci 9:42274235 .
Marcus EA, Nolen TG, Rankin CH, Carew TJ (1987) Behavioral dissociation of dishabituation, sensitization, and inhibition in the siphon withdrawal reflex of adult Aplysia. Soc Neurosci Abstr 13: 816.

Marcus EA, Nolen TG, Rankin CH, Carew TJ (1988) Behavioral dissociation of dishabituation, sensitization, and inhibition in $A p l y$ sia. Science 241:210-213.

Piomelli D, Volterra A, Dale N, Siegelbaum SA, Kandel ER, Schwartz JH, Belardetti F (1987) Lipoxygenase metabolites of arachidonic acid as second messengers for presynaptic inhibition of Aplysia sensory cells. Nature 328:38-43.

Rosen SC, Susswein AJ, Cropper EC, Weiss KR, Kupfermann I (1989) Selective modulation of spike duration by serotonin and the neuropeptides FMRFamide, $\mathrm{SCP}_{\mathrm{B}}$, buccalin, and myomodulin in different classes of mechanoafferent neurons in the cerebral ganglion of Aplysia. J Ncurosci 9:390-402.

Schaefer M, Piccioto M, Kreiner T, Kaldany R-R, Taussig R, Scheller RH (1985) Aplysia neurons express a gene encoding multiple FMRFamide neuropeptides. Cell 41:457-467.

Shimahara T, Tauc L (1976) Identification of a neuron inducing heterosynaptic facilitation on a specific synapse in Aplysia. Brain Res 118:142-146.

Shyamala M, Fisher JM, Scheller RH (1986) A neuropeptide precursor expressed in Aplysia neuron L5. DNA 5:203-208.

Small SA, Kandel ER, Hawkins RD (1989) Activity-dependent enhancement of presynaptic inhibition in Aplysia sensory neurons. Science 243:1603-1606.

Sweatt JD, Volterra A, Edmonds B, Karl KA, Siegelbaum SA, Kandel ER (1989) FMRFamide reverses protein phosphorylation produced by $5-\mathrm{HT}$ and cAMP in Aplysia sensory neurons. Nature 342:275278 .

Taussig R, Scheller RH (1986) The Aplysia FMRFamide gene encodes sequences related to mammalian brain peptides. DNA $5: 453-462$.

Teyke T, Weiss KR, Kupfermann I (1990) An identified neuron (CPR) evokes neuronal responses reflecting food arousal in Aplysia. Science 247:85-87.

Tomosky-Sykes TK (1978) Pharmacology of presynaptic facilitation of the gill-withdrawal reflex in Aplysia. Soc Neurosci Abstr 4:208.

Weiss KR, Koch UT, Koester J, Rosen SC, Kupfermann I (1982) The role of arousal in modulating feeding behavior of Aplysia: neural and behavioral studies. In: The neural basis of feeding and reward (Hoebel BG, Norin D, eds), pp 25-57. Brunswick, ME: Haer Institute. 